\title{
The Moods
}

\section{THE MOODS}

$\int$ ITERATURE differs from explanatory and scientific $\Delta$ writing in being wrought about a mood, or a community of moods, as the body is wrought about an invisible soul; and if it uses argument, theory, erudition, observation, and seems to grow hot in assertion or denial, it does so merely to make us partakers at the banquet of the moods. It seems to me that these moods are the labourers and messengers of the Ruler of All, the gods of ancient days still dwelling on their secret Olympus, the angels of more modern days ascending and descending upon their shining ladder; and that argument, theory, erudition, observation, are merely what Blake called 'little devils who fight for themselves,' illusions of our visible passing life, who must be made serve the moods, or we have no part in eternity. Everything that can be seen, touched, measured, explained, understood, argued over, is to the imaginative artist nothing more than a means, for he belongs to the invisible life, and delivers its ever new and ever ancient revelation. We hear much of his need for the restraints of reason, but the only restraint he can obey is the mysterious instinct that has made him an artist, and that teaches him to discover immortal moods in mortal desires, an undecaying hope in our trivial ambitions, a divine love in sexual passion.

1895 